\title{
PENINGKATAN MUTU PENDIDIKAN DALAM RANGKA MENINGKATKAN DAYA SAING PERGURUAN TINGGI UNTUK MENGHADAPI ERA GLOBALISASI
}

\author{
Sulaiman \\ STKIP YPUP Makassar
}

\begin{abstract}
ABSTRAK
Globalisasi merupakan era dimana setiap perguruan tinggi memiliki daya saing yang tinggi. Salah satu aspek yang mampu memberikan konstribusi dalam era tersebut, dalam perguruan tinggi adalah ketika lulusannya memiliki kompetesi yang berkualitas serta mampu bersaing dalam menghadapi tantangan yang semakin ketat. Oleh karena itu, setiap perguruan tinggi harus memiliki kreativitas dan inovasi yang saling mendukung. Sehingga tujuan yang diharapkan akan tercapai.
\end{abstract}

Kata Kunci: Daya Saing, Perguruan Tinggi, Era Globalisasi.

\section{PENDAHULUAN}

Dalam era globalisasi, dengan disepakatinya perdagangan bebas oleh Negara-negara di dunia merupakan peluang dan tantangan yang perlu diansipasi sejak dini. Untuk mengahadapi peluang dan tantangan tersebut factor paling menentukan adalah kemampuan daya saing nasional yang unsusr pelakunya meliputi seluruh stakeholder pembangunan baik dari sektor pemerintah maupun swasta dan masyarakat, termasuk di dalamnya Perguruan Tinggi sebagai penyelenggara pendidikan.

Pendidikan adalah investasi jangka panjang, sebagai sebuah investasi, pendidikan merupakan komoditi dalam pandangan ekonomi. Hal ini menempatkan bahwa penguasaan pengetahuan, keterampilan dan keahlian yang dihasilakan akan dimiliki oleh individuindividu dapat diukur dari sisi ekonomi yang dapat dikembangkan dalam jangka waktu tertentu, melalui jenis pekerjaan yang bisa didapatkan dengan tingkat kompetensi yang dimiliki dan latar belakang pendidikan yang dijalani.
Beberapa pendapat tentang hal ini seperti dikemukakan oleh Thomas $\mathrm{H}$. Jones, 1985 "The economics of education deals with relationship between educational spending and the well being of society as a whole or certainly social group”. Pendidikan ditempatkan sebagai jaminan dalam meningkatkan kehidupan yang baik dalam kehidupan kemasyarakatan sebagai individu dan bagian dari masyarakat (Wibowo, 1999).

Menjelang abad ke 21 dunia pendidikan tinggi mengahadapi tantangan yang cukup serius dalam perkembangannya. Ahir abad 21 yang ditandai derasnya arus globalisasi menyebabkan pengetahuan menjadi produk yang dominan dan memiliki peran signifikan dalam masyarakat. Masyarakat yang diwujudkan dalam fenomena ini adalah masyarakat yeng berpendidikan dan berpengetahuan, yaitu masyarakat yang berbasis pada informasi dan memiliki kemampuan untuk mengakses dan mengolah informasi tersebut secara kreatif (Drucker, 1989). Ciri spesifik dari masyarakat yang berpendidikan dan berpengetahuan adalah bertumpu pada pembelajaran secara mandiri dan 
berkelanjutan serta memiliki kemampuan berkomunikasi dan bekerja sama secara lintas budaya dala dunia yang tak terbatas.

Dalam era informasi ini, tantangan yang dihadapi perguruan tinggi dirasakan semakin menuntut langkah-langkah strategis agar tetap mampu memberikan sumbangan optimal kepada bangsa. Untuk itu dengan dirumuskan langkah-langkah antisipasi guna menjawab tantangan tersebut. Pandangan visioner, pemikiran kritis, dan semangat perubahan untuk mencapai cita-cita, serta mampu menghasilkan lulusan yang memiliki kompetensi yang unggul sesuai dengan bidangnya.

Sarjana sebagai produk perguruan tinggi mempunyai kompetensi yang besar untuk menjadi komponen penting dalam masyarakat yang berpendidikan dan berpengetahuan. Oleh karena itu kulaitas lulusan pendidikan tinggi adalah factor penentu dalam era globalisasi sekarang ini.

Jika kita perhatikan indikator Human Development Index (HDI), Indonesia masih sangat memprihatinkan, pada tahun 2002 nilainya 0,684 berada pada rangking 110. Pada tahun 2003 HDI Indoneia semakin memburuk menduduki peringkat 112 di bawah Vietnam (109), Thailand (74) dan Brunei Darusalam (31), Korea (30), dan Singapura (28). Selanjutnya pada tahun 2004 dan 2005 HDI Indonesia secara berturut-turut berada pada peringkat 111 dan 110. Menurut "The 2006 Global Economic Forum of Global Competiveness Index (GCI)" yang direlease World Economic Forum (WEF), daya saing global Indonesia kini berada pada poisi yang terpuruk.

Masalah SDM di Indonesia sangat komplek. Hal ini dicirikan oleh beberapa indikator berikut: Pertama, jumlah penduduk 219,20 juta (BPS, 2006); Kedua, pertumbuhan angkatan kerja lebih besar ketimbang ketersediaan lapangan kerja; Ketiga, itribusi penduduk antar daerah tidak merata; Keempat, ketidaksesuaian kompetensi SDM dengan pasar kerja; Kelima, ketidak-seimbangan kebutuhan layanan publik dengan jumlah petugas; Keenam, distribui informasi tentang pasar kerja yang lambat atau timpang; Ketujuh, demand yang belum terpetakan dengan baik; Kedelapan, tingginya tingkat pengangguran dan kemiskinan secara simultan menyebabkan rendahnya kualitas pendidikan dan kesehatan, dan pada akhirnya menyebabkan rendah kualitas SDM Indonesia.

Masalah pendidikan tinggi kini sedang menjadi topik pembicaraan yang aktual pada kalangan akademisi di Negara kita ini. Berbagai upaya tengah dilakukan untuk mengatasi persolan merosotnya mutu pendidikan secara umum. Upayaupaya itu meliputi berbagai program yaitu berbagai pelatihan bagi tenaga pengajar (dosen) dan perbaikan elemen-elemen pendidikan seperti kurikulum serta sarana prasarana fisik termasuk perpustakaan dan laboratorium, yang seluruhnya kemudian difokuskan pada pencapaian mutu untuk menjawab tantangan globalisasi.

Untuk menghadapi permasalahan tersebut yang terdapat pada dunia pendidikan tinggi serta rendahnya mutu pendidikan tinggi yang terjadi dewasa ini, beberapa pemikiran yang akan diuraikan untuk mencoba mencari jawaban atas permasalahan yang ada di dunia pendidikan tinggi khusnya di Indonesia.

\section{Daya Saing Perguruan Tinggi}

Salah satu faktor keunggulan nasional adalah tersedianya Sumberdaya Manusia (Human Resources): yang menguasai iptek dalam Jumlah besar, mutu dan memiliki daya beli yang memadai yang dihasilkan dari lembaga-lembaga pendidikan nantinya akan mendorong tumbuhnya industri berbasis ilmu pengetahuan yang dapat menyerap tenaga kerja produktif, yang dapat menghasilkan barang, jasa dan produk-produk yang berdaya saing tinggi. Asumsinya adalah untuk mendapatkan tenaga kerja yang berkualitas harus dilihat dari kualitas 
sistem pendidikan yang ada di suatu negara. Artinya, jika suatu negara memiliki sistem pendidikan yang baik, maka sistem itu akan mampu melahirkan tenaga kerja yang baik.

Menurut, UU No. 12 Tahun 2012. Tentang Pendidikan Tinggi, bahwa pendidikan tinggi sebagai bagian dari system pendidikan nasional memiliki peran strategis dalam mencerdaskan kehidupan bangsa dan memajukan ilmu pengetahuan dan teknologi dengan memperhatikan dan menerapkan nilai humaniora serta pembudayaan dan pemberdayaan bangsa Indonesia yang berkelanjutan. Selanjutnya , bahwa untuk meningkatkan daya saing bangsa dalam menghadapi globalisasi di segala bidang, diperlukan pendidikan tinggi yang mampu mengembangkan ilmu pengetahuan dan teknologi serta menghasilkan intelektual, ilmuwan, dan/atau profesional yang

berbudaya dan kreatif, toleran, demokratis, berkarakter tangguh, serta berani membela kebenaran untuk kepentingan bangsa.

Tridharma Perguruan Tinggi yang selanjutnya disebut Tridharma adalah kewajiban Perguruan Tinggi untuk menyelenggarakan Pendidikan, penelitian, dan pengabdian kepada masyarakat. Menurut Tilaar, (2004) lembaga pendidikan tinggi diarahkan kepada "research university". Pada tahap research university ini aktivitas utama dosen dan mahasiswa tidak lagi sekedar proses belajar mengajar di kelas melainkan sudah masuk kancah lapangan atau laboratorium riset untuk penemuan, pengembangan dan produksi ilmu pengetahuan yang diperoleh dengan kemampuannya menjalin kerjasama dalam konteks global. Dari aktivitas research inilah Perguruan Tinggi mendapatkan sumber dana dari paten yang dihasilkan para dosennya. Semakin bagus riset dilakukan dan semakin banyak paten yang dihasilkan maka akan semakin kaya dosen dan Perguruan Tingginya. Kalaupun belum mampu menghasilkan paten, risetriset yang datang dari pihak rekanan (user) sesungguhnya sudah cukup untuk meningkatkan kesejahteraan dosen dan staff. Inilah Perguruan Tinggi yang semestinya dapat melakukan peran untuk mencapai daya saing bangsa yang kuat. Perlu dilakukan penataan sistem pendidikan dengan paradigma baru, perlu penataan diri yang terintegrasi, terus menerus mengupayakan kreativitas dan inovasi, peningkatan relevansi pendidikan, perlu penyusunan renstra dan renop untuk memacu target yang sesuai indikator kinerja yang dinyatakan dalam kuantitas dan kualitas serta relevansi lulusan, bahkan prinsip link \& match supaya dapat diimplementasikan, dengan harapan pemerintah konsisten melakukan investasi dibidang pendidikan, peningkatan kualitas staf pengajar, sarana dan prasarana, meningkatkan keterlibatan seluruh civitas akademika melalui penataan organisasi, program, penggunaan dana yang efektif/efesien, saling tukar menukar pengalaman untuk mencapai kriteria Badan Akreditasi Nasional dalam peningkatan kemampuan pembelajaran supaya menghasilkan peningkatan kompetensi lulusan.

Mengapa kita semua harus menumbuhkan kreativitas dan inovasi dalam meningkatkan mutu pendidikan! karena pendidikan itu merupakan masalah bangsa, jika lulusan tak bermutu maka selain waktu dan biaya yang terbuang juga. Sumber Daya Manusia tidak akan mampu bersaing jika tidak berkualitas. Disinilah diperlukan adanya kepedulian yang tinggi terhadap Quality control dan Qualiti assurance. Dengan sistem inovasi antara lain kita akan: Menciptakan pengetahuan baru; Memandu arah proses pencarian penyedia dan pengguna teknologi, yaitu mempengaruhi arah agar para pelaku mengelola dan memanfaatkan sumber dayanya; Memasok/menyediakan sumber daya, yaitu modal, kompetensi dan sumber daya lainnya; Memfasilitasi penciptaan ekonomi eksternal yang positif (dalam bentuk pertukaran informasi, pengetahuan dan visi); Memfasilitasi formasi pasar. Tentu banyak "fungsi" penting inovasi 
selain yang disebutkan di atas. Banyak negara, mendorong pemajuan sistem inovasi antara lain dengan memperkuat kelembagaan dan infrastruktur khusus iptek, serta "keterkaitan" (linkages) antara pihak "penyedia solusi" dengan pihak "pengguna solusi." Instrumen kebijakan ini diharapkan dapat efektif dalam: meningkatkan sinergi (peran intermediasi) antarpihak dalam berinovasi, aktivitas difusi, dan proses pembelajaran; menjadi tempat/area bagi aktivitas penelitian, pengembangan, dan rekayasa produktif; menginkubasikan bisnis sehingga lahir perusahaan pemula atau baru yang inovatif; meningkatkan pertukaran informasi pengetahuan/teknologi; memberikan jasa layanan berbasis pengetahuan/teknologi dengan baik; memberikan bantuan teknis.

Pengembangan kelembagan dan infrastruktur iptek dalam implementasinya bukan hal yang mudah. Membangun keterkaitan, jejaring, dan sinergi dengan pemangku kepentingan kunci, termasuk masyarakat sekitar, merupakan hal yang sangat penting. Karena itu agenda peningkatan daya saing harus seiring sejalan dengan penguatan kohesi sosial. Hal lain adalah semakin mendesaknya kebutuhan akan terintegrasinya informasi dan komunikasi pengetahuan/ teknologi yang memudahkan baik pihak penyedia maupun pengguna.

Kreativitas menjadi sangat penting, oleh karena itu misi Perguruan Tinggi adalah mendidik mahasiswa kelak menjadi manusia-manusia yang kreatif, yang inovatif. Perguruan Tinggi menggunakan metodologi yang menggugah pikiran-pikiran mahasiswa menjadi berani men-challenge para dosen, para guru besar secara konstruktif, agar semuanya berkembang. Pendidikan harus membangun yang disebut dengan intellectual curiousity, rasa ingin tahu, mengapa bisa begitu, energi bagaimana, pangan bagaimana, climate change bagaimana, dan seterusnya. Kemudian mesti memiliki rasa bersaing yang tinggi.
Thinking outside the box. Kalau cara ini mentok, cari cara, masih mentok, cari yang lain, sampai bisa. Kemudian peran research and development, penelitian dan pengembangan. Pada akhirnya peran Perguruan Tinggi adalah mencetak puteraputeri bangsa yang cerdas dan berkarakter tangguh. Daya saing bangsa dapat dibangun dengan baik bila ditopang perguruan tinggi (PT) yang bagus dan kuat, yang mampu melahirkan orang terdidik, mahir, dan berkeahlian. Dalam konteks globalisasi, pendidikan tinggi memainkan peran sentral dalam membangun masyarakat berpengetahuan, tercermin pada munculnya lapisan kelas menengah terdidik dan kaum profesional yang menjadi kekuatan penentu kemajuan ekonomi. Mereka merupakan elemen pokok dalam menyokong ekonomi berbasis pengetahuan. Ilmu pengetahuan menjadi investasi modal yang amat penting, sekaligus faktor determinan dalam proses produksi. Sebab, aktivitas ekonomi lebih bersifat padat pengetahuan sehingga dukungan sumber daya alam menjadi berkurang.

Perguruan Tinggi diharapkan dapat menjadi tulang punggung yang utama transformasi sosial dan peningkatan daya saing bangsa dengan membentuk manusia yang menguasai ilmu pengetahuan, teknologi, dan/atau seni, dan berkualitas secara spiritual, emosional, intelektual, dan fisik serta memiliki profesionalitas dan kemampuan kepemimpinan serta jiwa kewirausahaan untuk mendukung peningkatan daya saing bangsa. Kerja akademik ini merupakan kewajiban sekaligus kehormatan bagi Perguruan Tinggi.

Pemerintah harus menempatkan pendidikan sebagai investasi jangka panjang mengingat kunci pembangunan manusia adalah pendidikan. Peran Perguruan Tinggi juga diperlukan akibat serbuan arus globalisasi dan berubahnya terus lapangan kerja. Sistem pendidikan harus mampu mewujudkan masyarakat yang belajar sepanjang hayat (long life 
$\begin{array}{llr}\text { learning). } & \text { "Harus diakui kalau } \\ \text { keberhasilan } & \text { pembangunan } & \text { yang }\end{array}$ berkelanjutan terletak pada kualitas sumber daya manusia yang unggul. Oleh karena itu, pembangunan manusia merupakan ujung tombak strategi pembangunan berkelanjutan. Dan, jalan untuk membentuk SDM berkualitas adalah melalui pendidikan" Langkah itu agar dapat mencerdaskan kehidupan bangsa dan mengembangkan jati diri, nilai luhur serta budaya bangsa-bangsa yang produktif dan kompetitif. Proses pendidikan perlu dikelola secara sungguh-sungguh agar generasi muda lebih bertakwa, berbudi pekerti luhur, dan berwawasan global sehingga mampu berperan positif bagi peningkatan kesejahteraan dan keunggulan bangsa.

Dalam hal ini, pendidikan tinggi harus diarahkan juga untuk meningkatkan daya saing bangsa. Sehingga mampu menghasilkan ilmu pengetahuan, teknologi, seni, dan budaya untuk kemandirian bangsa. Pengembangan unggulan diarahkan pada bidang-bidang yang relevan terhadap kepentingan masyarakat dan bangsa. Khususnya yang dapat memberikan nilai tambah pada hasil sumber daya alam secara berkelanjutan serta mengurangi ketergantungan dari pihak luar. Karena itu, sekali lagi, pemerintah harus mengembangkan sistem yang dapat menjamin kesetaraan akses pada pendidikan yang berkualitas. Lapangan kerja yang terus berubah serta globalisasi mengharuskan penyelenggaraan sistem pendidikan yang mampu mewujudkan masyarakat belajar sepanjang hayat.

\section{Permasalahan Pendidikan Tinggi.}

Meskipun berbeda dalam hal jenis dan kadarnya, problema pendidikan tinggi tidak hanya ditemui di Indonesia tetapi juga di Negara maju seperti Di Amerika Serikat. Di sana, seperti dalam laporan Bailey \& Bennet (1996), problema- problema tersebut umumnya terkait dengan masalah skill seperti problema dalam:

- kemampuan berkomunikasi baik secara lisan maupun tertulis;

- kemampuan analisis yang masih kurang;

- Penguasaan sophisticated poroblrm solving tools pada personal computer;

- kemamampuan kerja sama dalam tim baik sebagai pimpinan maupun anggota;

Sementara di Indonesia, dari berbagai diskusi informal dapat disimpulkan beberapa persolan sebagai berikut:

- tingkat kelulusan yang rendah pada hamper semua mata kuliah yang mengandung aspek analisis matematis;

- indeks prestasi mahasiswa yang ratarata berada di antara 2 dan 3;

- lama studi rata-rata antara lebih dari 5 tahun untuk program studi 4 tahun;

Ketiga persoalan ini kemudian bermuara pada kemampuan sarjana kita yang banyak dikeluhkan oleh dunia usaha dan industry sebagai penggunan lulusanlulusan tersebut. Krisis yang terjadi disini bukan hanya pada kualitas pengetahuan sarjana kita, tetapi juga kemampuan mereka bekerja pada lahan pekerjaan yang sesuai dengan latar belakang pendidikannya. Apabila tidak ada upaya berarti yang segera dilakukan masalah ini akan mengarah pada krisis kepercayaan bagi industry-industri nasional. Industry nasional nantinya mau tidak mau akan memilih tenaga-tenaga kerja asing yang memiliki kualitas dan kualifikasi untuk menempati pada posisi-posisi yang penting yang pada ahirnya kegagalan menjadi tuan rumah di negeri sendiri, dan ahirnya menjadi penontong di negeri sendiri.

Dalam kaitannya dengan uraian diatas, menarik untuk disimak adalah tulisan Santoso (1999) yang mencoba mengidentifikasikan penyebab persolanpersoalan yang ada: 
- kelemahan karakter mahasiswa, yang ditandai dengan adanya krisis etisnormatif yang semakin memprihatinkan dari mahasiswa hingga berpengaruh negative disiplin dan motivasi kerja;

- kelemahan karakter dosen, mengingat cukup banyak sebetulnya dosen yang tidak/belum pernah bersntuhan dengan industry/dunia kerja nyata, sehingga kurang dapat memberikan contoh riil dalam perkuliahan;

- kelemaahan kurikulum, yang terkait dengan rendahnya relevansi antara muatan kurikuler dan kebutuhan industry;

- kelemahan manajemen pendidikan.

Beberapa pihak mungkin akan mengatakan bahwa kualitas input dari calon mahasiswa yang cenderung menurun dari tahun ketahun juga merupakan factor negative dalam rangka pencapaian keberhasilan proses pendidikan tinggi. Variasi yang timbul dari jenjang pendidikan dasar hingga pendidikan menengah, ditambah variasi yang disebabkan kondisi geografis Negara Indonesia dari sabang sampai marauke yang menghasilkan berbagai variasi dari latar belakang adat istiadat dan bahas daerah yang beraneka ragam yang akan berdampak kepada interaksi di dalam proses belajar mengajar. Tapi marilah kita mencari pokok masalah yang dihadapi perguruan tinggi yang erat kaitannya dengan perbaikan mutu perguruan tinggi. Menurut (Ranuwihardjo,1999), masalah yang erat kaitannya dengan mutu perguruan tinggi adalah system pengelolaan perguruan tinggi yang sekarang dirasakan sudah tidak lagi memenuhi kebutuhan. Selanjutnya masalah variasi input calon mahasiswa adalah masalah eksternal. Sesuatu yang tidak terjamah oleh civitas perguruan tinggi. Tetapi selain itu masih banyak terdapat factor problem internal yang perlu dan dan sangat penting, dapat diperbaiki, mulai dari kualitas tenaga pengajar, fasilitas pembelajaran, kurikulum, manajemen dan lain-lain.

\section{Mutu Pendidikan Tinggi.}

Mutu selain didefinisikan oleh Phil Crosby sebagai kesesuaian atas suatu standar yang sudah ditetapkan (conforming to specifications), oleh Joseph Juran didefinisikan sebagai fitness for use atau kesesuaian terhadap mamfaat dari pemakai (Soin, 1992). Terllpas dari perbedaan makna harafiah kedua pengertian di atas, bagi proses pendidikan, pertanyaanpertanyaan berikut menarik untuk didiskusikan:

- jika mutu diartikan sebagai kesesuaian atas standar, apa standar yang dapat digunakan dalam mengukur proses pendidikan.

- jika mutu diartikan sebagai kesesuaian terhadap manfaat dari pemakaian, siapakah sebenarnya yang disebut pemakai/ konsumen proses pendidikan.

Jawaban dari kedua pertanyaan diatas jelas akan berbeda jika dibandingkan kedua pertanyaan tersebut ditujukan pada proses manufaktur. Tetapi antara proses pendidikan dan manufaktur dapat dibuat analogi yang dapat dilihat pada gambar 1 .

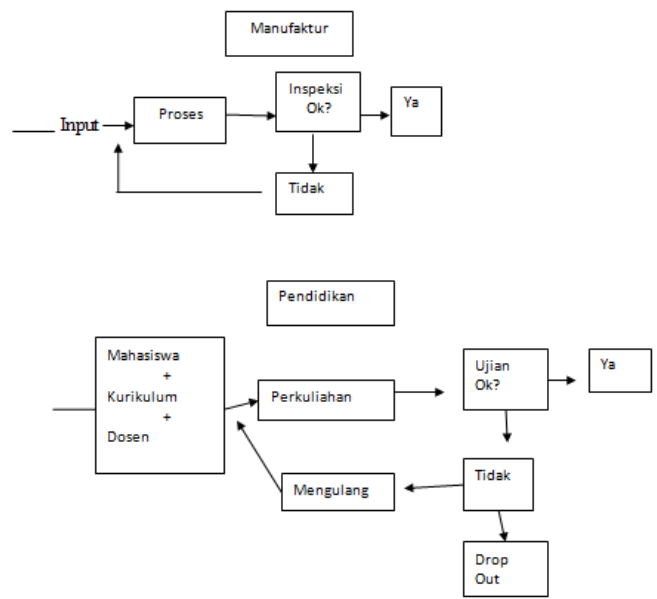

Gambar 1 Proses manufaktur dan Pendidikan 
Secara implisit dari gambar di atas, terlihat bahwa sebenarnya pemakai/konsumen dari proses pendidikan adalah dunua industry sebagai pasar penyerap tenaga kerja yang dihasilkan oleh perguruan tinggi. Dilain pihak, mahasiswa merupakan konsumen pendidikan dalam bentuk lain yang ukuran pemenuhan mutunya di tinjau dari segi proses pembelajaran. Apabila proses pembelajaran berlangsung menyenangkan dan dapat dinikmati, maka dikatakan bahwa proses pembelajaran tersebut adalah bermutu, sebernarnya masih terdapat pihak-pihak lain yang dapat disebut konsumen pendidikan seperti orang tua mahasiswa yang dapat diibaratkan sebagai investor,dan juga pemerintah. Tetapi mutu kulminasi mutu dari proses pendidikan tinggi seharusnya adalah keberhasilan institusi pendidikan tinggi dalam menghasilkan lulusan yang sesuai dengan kebutuhan dunia kerja.

Bertitik tolak dari pemikiran diatas, sangatlah penting bagi institusi pendidikan tinggi untuk memenuhi secara persis kebutuhan dunia kerja. Bila industry disebut sebagai konsumen pendidikan, maka masukan dari mereka tentang "spesipikasi produk"yang diinginkan merupakan informasi yang sangat berharga. Penggalian informasi tersebut walaupun tidak mudah bisa dilakukan dengan beberapa cara, misalnya menggunakan pendekatan Quality Function Deployment (Ermer, 1995), survey lewat angket, seminar dan lain-lain. Metode yang paling cocok tentunya harus disesuaikan dengan sumber daya yang ada pada institusi tersebut, tetapi pokok pembicaraan yang penting di sini adalah bahwa spesifikasi produk tersebut harus datang dari konsumen dan tidak semata ditentukan secara internal melalui kebijakan institusi.

Dari perumusan kebutuhan tersebut barulah tinjauan terhadap proses dapat dilakukan dengan baik. Artinya, baik tinjauan pada proses maupun input (dalam hal ini input yang dapat dikendalikan seperti kurikulum dan kualitas tenaga pengajar), harus selalu mengacu pada kebutuhan yang sudah dispesifikasikan pada out put. Dengan demikian kunci sukses dalam perbaikan kualitas, baik proses manufaktur maupun pendidikan tinggi, tidak hanya terletak pada kemampuan menangkap apa yang dibutuhkan oleh konsumen, tetapi juga bagaimana kebutuhan tersebut dapat dipenuhi secara efektif dan efisien. Komitmen pada pelayanan terhadap konsumen ini banyak kasus telah terbukti sebagai salah satu factor keberhasilan pemenuhan standar kualitas.

\section{SIMPULAN}

Kemampuan daya saing perguruan tinggi merupakan salah satu syarat mutlak yang diperlukan agar dapat memanfaatkan peluang dan mengatasi tantangan yang muncul akibat globalisasi. Salah satu faktor penentu daya saing perguruan tinggi adalah mutu pendidikan perguruan tinggi. Oleh karena itu program peningkatan mutu pada proses pendidikan di perguruan tinggi merupakan hal pokok yang harus ditempuh oleh lembaga-lembaga pendidikan tinggi untuk memperbaiki kualitas lulusan sehingga dapat menjawab tantangan globalisasi. Bila ditinjau dari keseriusan pemerintah adalam hal ini, sudah sepantasnya apabila lembaga-lembaga pendidikan tinggi juga mempunyai komitmen mulai dari atas Ketua/Rektor ke bawah seluruh karyawan untuk mengarungi siklus peningkatan kualitas yang berkelanjutan. Top-down commitment atau pemberdayaan dari atas ke bawah inilah mutlak diperlukan bagi suksesnya program yang berkualitas.

Akreditasi secara nasional saja mungkin tidak cukup untuk menghadapi ancaman dominasi lapangan kerja vital dari sarjana dan lulusan luar negeri. Menghadapi persaingan internasinal diperlukan tolak ukur yang bersifat internasional pula. 
Untuk proses internal, perbaikan dapat dilakukan misalnya system penilaian dan kualitas tenaga pengajar. Tenaga pengajar ideal yang dibutuhkan masa depan bukan hanya sekedar insan dengan penguasaan substansi akademik yang tinggi, tetapi juga harus ahli dalam penyelenggaraan proses pembelajaran serta memiliki sikap yang baik selaku seorang pendidik. Pengajaran tidak lagi menjadi metode yang layak digunakan di perguruan tinggi, melainkan pembelajaran. Tanggungjawab pendidikan harus samasama di pikul oleh dosen dan mahasiswa karena dosen berfungsi sebagai fasilisator. Dengan demikian akan tercapai hakiat proses pendidikan sejati yaitu mahasiswa belajar, bukan dosen mengajar.

\section{DAFTAR PUSTAKA}

Bailey, Bennet, Duncan \& Jerome V. 1986. The Realistick Model of Higher Education. Quality Progress.

Drucker, Peter F. 1989. The New Realities New York: Harperd Row;

Ermer, Donald. S. 1995. Using QFD Becomes an Educational Experience For Students and

Faculty. Quality Progress.

Santoso, Sam. 1999. Tantangan Pembangunan Universitas Abad XXI. Membangun Pradigma Baru: Universitas Surabaya;

Tilaar, 2004. Manajemen Pendidikan nasional. Bandung: Remaja Rosdakarya.

Wibisono, Eric, 1999. Tinjauan Atas Paradigma Kualitas Dalam Pendidikan Tinggi Indonesia. Unitas Vol. 7. No. 2

Undang-Undang Nomor 12 Tahun 2012, Tentang Pendidikan Tinggi. 